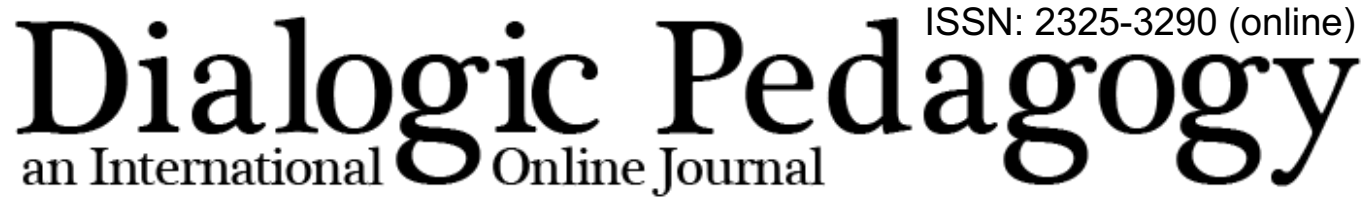

\section{Education-for-Myself and Education-for-the Other: The Right to Freedom of Education and Mikhail Bakhtin's Experience}

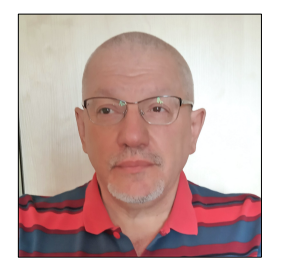

Oleg Osovsky

Mordovia State Pedagogical

Institute, Russia

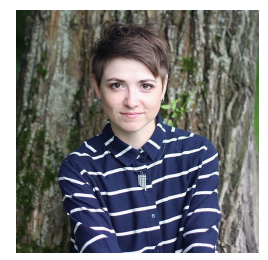

Ekaterina Chernetsova

National Research University Higher

School of Economics, Russia

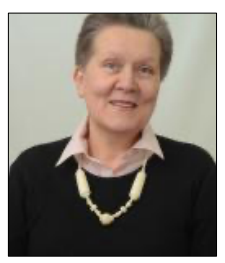

Vera Kirzhaeva

National Research Mordovia State

University, Russia

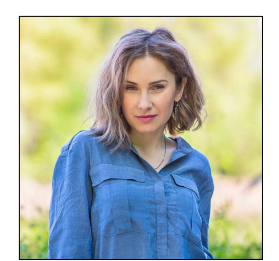

Elizaveta Maslova

Plekhanov Russian University of

Economics, Russia

\begin{abstract}
The article contains reflections on the problem which has arised in Eugene Matusov's article on freedom of education, and considers the experience of Mikhail Bakhtin as an example of the way the right to the freedom can be fulfilled. Not only Bakhtin's life and ideas play a significant role in contemporary social and educational theories and practices, but they reveal how education becomes a result of selection of particular knowledge and one's conscious choice. The core of the article is a correlation of notions "Education-for-myself" and "Education-for-the other" which are taken by the authors as derivatives of the terms of Bakhtin's early philosophy "I-for-myself" and "I-for-the other". Thus ideas of "Education-for-an individual" and "Education-for-the society" result from the reflections and can be evidence of the need in mutual understanding and dialogue in order to achieve freedom of education.
\end{abstract}

Oleg Osovsky works as a Chief research fellow in pedagogical institute in Saransk. He is a Dr. of Philology. Professor Osovskiy is the author of several books on M.B Bakhtin's ideas and their reception in Anglo-American humanities, Russian émigré school in Europe.

Vera Kirzhaeva works as a professor of Russian at Philology department in Saransk. She is a Dr. of Pedagogy. Her main research interests are Bakhtin Studies, Russian émigré education in 1920-40s, Russian intellectual history.

Ekaterina Chernetsova is an Associate Professor in School of Foreign Languages at Higher School of Economics (Moscow). She specializes in American Studies and World Literature, problems of teaching languages and literature. Her research also focuses on contemporary American fiction, clash of paradigms in literature, and Bakhtinian approaches to a literary text. Her recent book is Chernetsova E. (2018) After New Journalism: History, Myth, Imagination in Norman Mailer's novels of the 1980-s - 2000-s.

Elizaveta Maslova works as a university lecturer in Moscow. She holds a PhD degree, CELTA and FTBE. Her special interests include LCCl exams preparation and development of online courses, Bakhtin and contemporary US novel. 


\section{Education-for-Myself and Education-for-the Other: The Right to Freedom of Education and Mikhail Bakhtin's Experience \\ Oleg Osovsky, Vera Kirzhaeva, Ekaterina Chernetsova, Elizaveta Maslova}

\section{2बS}

Professor Eugene Matusov wrote a serious and crucial article which in many respects reflects a whole range of the most complicated problems closely linked to a changing image of the contemporary education. It seems a student's right to freedom of education is an inviolable right, and even if it is not warranted by national or international legislations, educational communities quite realize its value. The author brilliantly stated the way he sees freedom of education. As a whole his vision of this notion doesn't provoke any objections. But other questions arise at this point:

- What does the notion of freedom of education involve?

- How can the right to this freedom be realized in a particular situation of a particular country?

- Does this right depend on whether this is a democratic, authoritarian, totalitarian early industrial, postindustrial or digital state?

Moreover, we have faced the problem of distance learning within the frames of the COVID-19 pandemic and its restrictions and difficulties - methodological, technological, and psychological. So Professor Matusov suppositions are crucial concerning the reality we are living in, his ideas about a student's right to freedom of education are becoming a discussion about whether this freedom is possible in conditions of almost total inability to be free which is not dictated by someone's malice but determined by the epidemiologic situation in the world.

In other circumstances we could have begun by considering the article as a project dealing with traditions of the western pedagogic utopia tradition, which traces its origins to Dialogues by Plato and Cyropaedia by Xenophon, to social philosophic utopias of the Renaissance (such as The Abbey of Thelema by Rabelais), to numerous projects of the XVII-XVIII th centuries (primarily French and English Enlightenment), to reformatory constructions in the age of transition from industrial to postindustrial society. Do we have to unconditionally support the thesis that the right to freedom in education support is that the right to freedom of a learner is an integral part of all human rights? Solutions of the problems linked to

Obviously, the solutions of the problems related to the implementation of this right depend on the national education system, the economic and intellectual capabilities of a country and the readiness of the professional community and society as a whole to accept this right as legitimate. In this context, historical experience is also important, which allows one to see precedents that may be in demand today in terms of national school reforms or changes in national education systems in the era of crises and revolutions. But no less, and perhaps more important, are personal stories of those who, at different periods of the world upheavals, gained their own experience in getting education as a result of their conscious choice and selection of certain body of knowledge (from Benjamin Franklin and Jack London to Steve Jobs and Bill Gates).

In this regard, it seems quite natural that reflection on the article by Professor Matusov made us think of Mikhail Bakhtin, whose ideas play an increasingly important role in modern social and educational theory and practice (see Matusov 2019; Osovsky 2018; Chernetsova, Maslova, Salski 2018; Chernetsova, Maslova 2019). Speaking about Bakhtin's biography, it's difficult to resist temptation to build a construction related to the terms of Bakhtin's early philosophy "I-for-myself" and "I-for-the other", replacing "I" with the term "Education". "Education-for-myself" and "Education-for-the-other" - how do they correlate in Bakhtin's life? how do they interact? where do they match? 


\section{Education-for-Myself and Education-for-the Other: The Right to Freedom of Education and Mikhail Bakhtin's Experience \\ Oleg Osovsky, Vera Kirzhaeva, Ekaterina Chernetsova, Elizaveta Maslova}

\section{"Education-for-myself": Mikhail Bakhtin's experience}

A brilliant thinker Mikhail Bakhtin creates himself, without going through a single formal educational institution, gaining his philosophical, wider-intellectual view of the world and culture via exploration of scientific heritage created in previous eras, and thereby he demonstrates the highest degree of freedom of education, the right which he could realize due to the circumstances of his own life, as we try to show.

The facts of Bakhtin's early biography are not supported by a lot of documentary evidence. Biographers, including Michael Holquist and Katerina Clark (Clark \& Holquist 1984), Semyon Konkin (Konkin 1984; Konkin \& Konkina 1993), Vladimir Laptun (Laptun, 1993; Laptun \& Tihanov 2018), Svetlana Dubrovskaya (Dubrovskaya 2017), Nikolai Nikolaev (Nikolaev 1998; 2017) and the best of Bakhtin's biographers, the creator of Dialog. Carnival. Chronotope journal Nikolai Pankov (Pan'kov 2010), do not give definitive answers to the question of what the level of Bakhtin's formal education was. The only document that has been preserved in Bakhtin's archive and that confirms his formal right to conduct teaching is a candidate of philological sciences diploma, received in 1952, that is 6 years after defending his dissertation on Rabelais (see Dubrovskaya 2014). No other documents on education were found by researchers. There is no doubt that if these documents existed, they would have been preserved in the family archive, as was his wife's gymnasium certificate kept in it. In the modern Bakhtin studies, there is a tendency to speculate that Bakhtin had not formally received even secondary education. The only document available dates back to 1912: Mikhail is 16 and a half years old, and, having received a commendation for success in studying in his fourth year of the classical gymnasium ${ }^{1}$, but being two years late compared to his peers, he is transferred to the fifth year. It is easy to calculate, taking into account requirements of the educational system in those days and at a normal pace of studying, Bakhtin must have completed his full eight-year course of gymnasium in 1916 at the age of 20. Finishing high school at that age was not something exceptional (for instance, a prominent Russian Medievalist and literary critic, the author of perhaps the best review of Bakhtin's Problems of Dostoevsky's Poetics, Professor Peter Bitsilli left Odessa gymnasium at the age of 20 due to his illness). But evidence of Bakhtin's further training in gymnasium cannot be found, and it seems plausible to conclude that he received all his extensive knowledge in humanities only by means of self-education.

It should be pointed out that traditions of homeschooling, originating in the Bakhtins family, contributed to this. According to the recollections of his elder brother Nicolay, boys already in childhood were fond of the classical age poetry and culture, under the supervision of a German bonne, they performed scenes from the Homeric "lliad" in the German language, were absorbed by classical Russian literature, and argued about serious philosophical subjects (Bakhtin 1963, 1). According to Bakhtin himself, by the age of 14 he had read all of Dostoevsky, read I. Kant in German, a little later got acquainted with the treatise by $\mathrm{S}$. Kierkegaard and even wanted to learn Danish in order to compare the German translations and original texts: "I already knew Dostoevsky at the age of eleven-twelve. And a little later, at the age of twelve or thirteen, I already began to read serious classical books. In particular, I knew Kant very early, I started reading his "The Critique of Pure Reason" very early $<\ldots>$ I read him in German $<\ldots>$ In Russian, I only read "Prolegomenas". "Prolegomenas" translated by Vladimir Solovyov. This was what I read." Young Bakhtin's concentration on philosophy and history of culture, comprehension of world and Russian classics was largely determined by a serious illness: "I had a disease in childhood $\langle\ldots\rangle$ which, in essence, still has not somehow left me. This is called osteomyelitis" (Bakhtin 2002, 41).

\footnotetext{
${ }^{1}$ In prerevolutionary Russia, as a rule, children, of the privileged classes entered "the classical gymnasium" at the age of 10 and graduated at 18, gaining the right to enter the university. Due to illness, Bakhtin failed a year twice, thereby seriously falling behind his peers.
} 


\section{Education-for-Myself and Education-for-the Other: The Right to Freedom of Education and Mikhail Bakhtin's Experience \\ Oleg Osovsky, Vera Kirzhaeva, Ekaterina Chernetsova, Elizaveta Maslova}

The experience of Bakhtin as a teenager can be a convincing illustration of what Professor Matusov says about homeschooling as a form of fulfilling freedom of education. The Bakhtin brothers, with only a year age gap, were so close psychologically that the elder's university life could not but change Mikhail's attitude to the gymnasium. Although in conversations with Victor Duvakin he shows affection speaking about the gymnasium years, he is much more enthusiastic about what happened to him at universities. Here we are again embarking on making assumptions, but there is no doubt that Bakhtin knew the university life of Odessa and Petrograd very well. It is difficult to say how often he appeared in university classrooms, apparently trying to attend lectures of those professors that were of particular interest to him; but the very fact of Bakhtin's communication with university teachers is undeniable. There is also important official evidence. For instance, one of the greatest Russian linguists, was academician Viktor Vinogradov, whose ideas were criticized in many Bakhtin's works, which was well known to Vinogradov. However, speaking in support of Bakhtin's dissertation at a meeting of the Higher Attestation Committee, Vinogradov noted: "Bakhtin is almost my Leningrad University friend" (see Osovsky 2017).

In Bakhtin's memoirs, remarkable details have been preserved of his conversation with a famous psychologist and teacher, the head of the Department of Philosophy of Odessa University, Professor Nikolai Lange. It is impossible not to pay attention to the fact that an experienced teacher and a 19-year-old boy are having a conversation as equals: "He was a great professor < .. > but, for example, when, as I remember, I asked him - since I started reading philosophical books very early in the original, in German, - I asked him regarding Hermann Cohen - this is the head of the Marburg school $<\ldots>$ I asked him if this was a solid book. He replied to me: "It seems pretty solid." That means he did not read it. And moreover, it seemed to me that he knew the name of Hermann Cohen only by hearsay." The Department of Philosophy of Petrograd University becomes for Bakhtin completion of his "neo-Kantian universities", the school where his own philosophical thinking is finally burnished and a very independent and original prospective thinker is prepared: "In general, the Department of Philosophy was very interesting and very lively <...> The department head was Alexander Ivanovich Vvedensky $<\ldots>$ He was a strict, consistent Kantian, not even a neo-Kantian, but a representative of pure Kantianism. This was the head of the department. Well, one of associate professors, and later professors, was Nikolai Onufrievich Lossky. It was the most striking and vivid figure at the faculty. He held completely different views. He was the most striking and vivid figure at the faculty. He held completely different views. He was not a Kantian, he could even be called anti-Kantian. He was an intuitionist" (Bakhtin 2002, 63).

Bakhtin at this time was not only interested in philosophy. He got acquainted with the greatest representatives of Petrograd literary life, culture of the Silver $\mathrm{Age}^{2}$ as a whole, joined various literary circles and associations, attended meetings of Religious and Philosophical Society, home seminars of the greatest philologist and specialist in antiquity Tadeusz Zelinsky. The lessons of his father-financier are not in vain: he masters practical accounting and, according to some evidence, he even serves in one of the bank branches in Petrograd; subsequently, these skills will help him to make a living in exile in Kustanai, where he managed to get an economist position in the local Consumer Union and even to conduct a course in accounting (Clark \& Holquist 1984; Konkin \& Konkina 1993). By the way, the fact he knew German was also useful to him. In the late 1920-s, he began translating the "Theories of the novel" by D. Lukacs into Russian but refused to finish this project when it turned out that the author had radically revised his views. During the war he began to teach not only history, Russian, and literature, but also German.

\footnotetext{
${ }^{2}$ The Silver Age - a period in the history of Russian literature and culture, the 1890s - 1910s. It is marked by significant artistic discoveries and achievements, the flourishing of Russian symbolism and avant-garde movements in Russian poetry, prose and drama, music, religious philosophy.
} 


\section{Education-for-Myself and Education-for-the Other: The Right to Freedom of Education and Mikhail Bakhtin's Experience \\ Oleg Osovsky, Vera Kirzhaeva, Ekaterina Chernetsova, Elizaveta Maslova}

Bakhtin exercised the right to freedom of education throughout his life, gradually mastering new levels of humanitarian knowledge in the 1920s, 1930s, 1950s, moving to new research topics - from moral philosophy and aesthetics of verbal creation to problems of Dostoevsky's poetics, theory of the novel, conceptualization of laughter in Rabelais, speech genres and dialogue of cultures.

\section{"Education-for-the-Other": the path from Nevel to Saransk}

In 1918, fleeing starvation and devastation in the post-revolutionary Petrograd, Bakhtin moved to Nevel, a small town on the border of Russia and Belarus, where a friend of his elder brother's, a philosopher and literary critic Lev Pumpyansky, invited him. Bakhtin taught first in the male gymnasium, then in a unified labor school ${ }^{3}$. He even made a kind of pedagogical career: he was elected as the chairman of the secondary school council. The proceedings of the council meetings discovered by Nikolai Pankov preserved details of the uncompromising struggle of teachers and students for the right to freedom of education. The Nevel school, just like the other schools of Soviet Russia, survived difficult conditions, when the communist administrative apparatus, extremely unprofessional at the local level and having little to do with education, seeked to impose a new vision of goals and objectives of education. Bakhtin and his like-minded friends were trying to resist this dictate. Among them one should particularly mention Matvei Kagan, a Ph.D. of Marburg University, and a beloved student of Hermann Cohen.

It seems that Bakhtin and Kagan would agree with the opinion of another Russian neo-Kantian philosopher and educator Sergei Hessen: “...enforcement, whose true origin should be sought not in the external world but in the internal world of a child, can again be destroyed only by the internal power of a person that can withstand all the enforcement, and not by simply abolishing this enforcement, always partially if necessary. It is precisely because enforcement can really be cancelled only by the very gradually growing personality of a person, liberty is not a fact, but a purpose, not a given, but the task of education. And if so, then the very alternative to free or forced education fails, liberty and enforcement are not opposed but mutually penetrating principles" (Hessen 1923, 57). In the cited book Basics of Pedagogy. Introduction to Applied Philosophy, published in 1923 in Berlin, but conceived and started in Tomsk in 1918-1919, the largest theoretician of pedagogy of the Russian émigrés set forth his vision of the most important problems of education. It is noteworthy that the first chapters of the book are devoted to the problems of free education and the balance of discipline and freedom in the educational process. Hessen's book was highly praised by the European pedagogy and ranked among the most important for the pedagogical audience of Czechoslovakia, Poland, Yugoslavia and Italy in the 1930s (see Osovsky \& Kirzhaeva 2017).

Among the issues discussed at the school council meetings in Nevel, were the issue of curriculum changes, the selection of new subjects, and the optimization of the educational process. It is significant that despite the ideological dictatorship, the council defended the right of students to comprehensive education: "Representative of the department of public education "comrade Shiryakov" proposed "a new Study of socialism". However, "comrade Bakhtin" said that "while teaching Sociology, it will also be necessary to look in detail at the history of socialism, and therefore there is no need to single out doctrine of socialism as a special subject". The participants of the meeting supported Bakhtin. Then Kagan spoke in favor of starting teaching English at school, and Gorbatsky - in favor of teaching Latin, fencing and boxing. The meeting approved these subjects as optional for those who wish" (Pan'kov 1998, 100). Other forms of work with students were also used in Nevel, for example, mass theatrical performances ${ }^{4}$, which were popular in the immediate post-revolutionary years. Thus, the Nevel newspaper Molot in the issue of May 27, 1919

\footnotetext{
${ }^{3}$ The type of a comprehensive seven-years school in Soviet Russia in 1918-1920s

${ }^{4}$ One of the most popular forms of the revolutionary and cultural propaganda. It needed a large number of non-professional actors and was organized for the working masses in the open air.
} 


\section{Education-for-Myself and Education-for-the Other: The Right to Freedom of Education and Mikhail Bakhtin's Experience \\ Oleg Osovsky, Vera Kirzhaeva, Ekaterina Chernetsova, Elizaveta Maslova}

reports that "an open-air performance of the Greek tragedy by Sophocles Oedipus in Colonna ${ }^{5}$ is being prepared. Students from city and county labor schools, numbering over 500, are involved. The production is directed by experts on Hellas and Greece comr. Bakhtin and comr. Pumpyansky" (Maksimovskaya 1996, 150).

The most important form of "Education-for-the other" for Bakhtin himself are the public and private lectures. While in Petrograd he was mainly a listener, in Nevel, Vitebsk and Leningrad he was a frequent and in-demand lecturer. It should be mentioned that it also helped Bakhtin to make his living, since in the 1920-1930s he basically did not have a permanent job. The Molot newspaper preserved evidence of a wide range of topics and plots that Bakhtin spoke on to a very diverse audience. Among these talks were On Friedrich Nietzsche's Attitude to Christianity, On the Meaning of Life, Leonardo's World View, Chekhov's Personality and Writing, Russian National Character in Literature and Philosophy. Bakhtin is even more in demand as a lecturer in Vitebsk, where he moved in the fall of 1920 to teach at the People's Conservatory and at the local institute of public education. The Vitebsk journal Art in 1921 announces the lecture at the newly opened club of the Union of Art Workers: "M.M. Bakhtin on the topic Art and Reality and K.S. Malevich on the new art and production" (see Osovsky 1993). The name of the outstanding innovative artist Kazimir Malevich next to the name of Bakhtin is the best confirmation of the role that Bakhtin played in culture of Vitebsk at that time. According to the recollections of listeners, the topics of lectures delivered by Bakhtin from September 1920 to April 1921 included aesthetics, new Russian philosophy, ethics, culture, literature and the latest Russian poetry.

Having arrived from Vitebsk to Leningrad in 1924, Bakhtin immediately began lecturing for a limited audience, close to him in spirit, which included mostly friends and acquaintances. Bakhtin's faithful friend, world-famous pianist, heroine of the black comedy The Death of Stalin, Maria Yudina wrote in October of that year to Yulalia Casanovich: "I welcome you to the lecture by M. Bakhtin about Dostoevsky this week, I will inform you about the exact time" (Yudina, p. 92).

A great example of the role that Bakhtin's lectures played in the learning process of his audience at different stages of their lives can be found in Rakhil Mirkina's story. She got acquainted with Bakhtin in high school in Vitebsk, when she and her sister attended Bakhtin's home seminar on Russian literature: "Mikhal Mikhalych gave excellent lectures. He was a born speaker with a very expressive, beautiful voice. His speech flew free and relaxed. He never used notes, plans, neither did he prepare quotes. Some of the heaviness inherent in his printed works disappeared in his oral speeches. He created an impression of a brilliant improviser, enthusiastic and emotional. He recited verses in a chant, and it seemed that it was not a lecturer or reciter who read them, but a poet - the author himself.

Bakhtin, of course, took into account the composition of the audience, but giving popular lectures to the general public, he never simplified anything. This ability to combine simplicity of presentation with deep analysis was also characteristic of Mikhal Mikhalych" (Mirkina 1993, 94). Having already become students at the Leningrad Institute of Art History, the Mirkin sisters found Bakhtin in Leningrad to continue their studies in Bakhtin's seminars that he would teach specifically for them.

From the late 1940 - early 1960s, Bakhtin continued to lecture in the so-called cultural education system in Saransk, giving lectures for members of the Union of Writers, Mordovian branch of the VTO (AllRussian Theatrical Society), school for the music college teachers, and students of various evening

5 The text is full of reporter's mistakes: from the Russian 'колонна' /kəlona/ which has similar spelling with 'Колона' /kәlоna/ the Russian translation of the original 'Colonus'; 'Hellas and Greece' instead of Greece; Pompyansky instead of Pumpyansky 


\section{Education-for-Myself and Education-for-the Other: The Right to Freedom of Education and Mikhail Bakhtin's Experience \\ Oleg Osovsky, Vera Kirzhaeva, Ekaterina Chernetsova, Elizaveta Maslova}

courses. Bakhtin was quite free in the choice of material for his lectures, which can easily be demonstrated in the published lecture on the Marxist-Leninist aesthetics of 1958. Along with quite traditional figures from the history of European aesthetics of the classical era, it included Theodor Lipps with his "theory of empathy" and even Sigmund Freud with his psychoanalysis ${ }^{6}$. This freedom, as we might assume, had a special value for Bakhtin himself, who exercised in his lectures his own right to freedom of education and freedom of pedagogical expression, as he said, "on this barren ground, under this unfree sky".

It is important to emphasize Bakhtin's special attitude to this type of speech because he did not assess his lectures for the student audience as very good, acknowledging their being dependent on his general ideological attitudes in private conversations, for example, with the literary critic Alexander Chudakov (see Chudakov 2013).

To summarize, we would note that one or more personal stories, of course, are not enough to draw a final conclusion on how an individual model of freedom of education should be implemented today. We agree with Professor Matusov's opinion that the right to freedom of education should be realized on the level of personal responsibility of everyone, which is, perhaps, another point of contact with the philosophy of Mikhail Bakhtin. The right to freedom of education should be fulfilled through the consensus of an individual and the society, an individual's understanding of what "Education-for-the individual" is, the society's understanding of what "Education-for-the society" is. It is here that mutual understanding and the dialogue developing on its basis should arise.

\section{References}

Bachtin, N. (1963). Lectures and essays. Birmingham.

Bakhtin, M. M. (1997). Sobraniye sochineniy [Collected Works]. Moscow: Russkiye Slovari.

Bakhtin, M. M. (1993). Toward a philosophy of the act (V. Liapunov, Trans. 1st ed.). Austin: University of Texas Press.

Bakhtin, M. M. \& Duvakin, V. D. (2002). M. M. Bakhtin: Besedy s V. D. Duvakinym [M. M. Bakhtin: Conversations with Duvakin]. Moscow: Soglasiye.

Chernetsova E. V. \& Maslova E.G., The Alien City Chronotope within the Scope of Toni Morrison's Jazz // 3L: Language, Linguistics, Literature. 2019, Vol. 25, No. 1, pp. 43-54.

Chernetsova E. V, Maslova E. G, Salski L. Implementation of Integrative Approach in Teaching American Studies in Institutions of Higher Education // Integration of Education, 2018, Vol. 22, № 1, pp. $120-133$.

Chudakov, A. P. (2013). Sbornik pamyati [Memory Collection]. Moskva: Yazyki Slavyanskoy Kul'tury, pp. 109-158.

Clark, K. \& Holquist, M. (1984). Mikhail Bakhtin. Cambridge: Harvard University Press.

Dubrovskaya, S. (2014). "Gogol' i Rable" kak syuzhet otechestvennogo literaturovedeniya 1940-1980-kh gg. ["Gogol and Rabelais" as the plot of Russian literary criticism of the 1940-1980s] // Izvestiya Rossiyskoy akademii nauk. Seriya literatury i yazyka, 73 (6), pp. 62-71.

$6 \quad$ https://bakhtin.mrsu.ru/wp-content/uploads/2020/04/2020-\%E2\%84\%963-\%D0\%9A\%D0\%BB\%D1\%8E\%D0\%B5\%D0\%B2\%D0\%B0\%D0\%98.\%D0\%92.pdf 


\section{Education-for-Myself and Education-for-the Other: The Right to Freedom of Education and Mikhail Bakhtin's Experience \\ Oleg Osovsky, Vera Kirzhaeva, Ekaterina Chernetsova, Elizaveta Maslova}

Dubrovskaya, S. (2017). S.D. Er'zya i N.I. Shibakov: novyye materialy po istorii kul'tury i iskusstva Mordovii 1950-70-kh godov [S.D. Erzya and N.I. Shibakov: new materials on the history of culture and art of Mordovia in the 1950s and 70s] // Vestnik ugrovedeniya, 7, 3 (30), pp. 169-171.

Hessen, S. (1923). Osnovy pedagogiki. Vvedeniye v prikladnuyu filosofiyu [Fundamentals of pedagogy. Introduction to applied philosophy]. Berlin: Slovo.

Konkin, S. S. (1984) Put' uchenogo: Stranitsy zhizni i tvorchestva M. M. Bakhtina [The path of the scientist: Pages of life and work of M. M. Bakhtin] // Grani: literaturno-khudozhestvennyy sbornik. Saransk: Mordovskoye Knizhnoye Izdatelstvo, 213-230.

Konkin, S. S, \& Konkina, L. S. (1993). Mikhail Bakhtin: Stranitsy zhizni i tvorchestva. [Mikhail Bakhtin: Life and Creative Work]. Saransk. Mordovskoye Knizhnoye Izdatelstvo.

Laptun, V. I. (1996). Perviy priezd M. M. Bakhtina v Saransk (1936-1937) [The first visit of M.M. Bakhtin to Saransk (1936-1937)]. Nevelskiy Sbornik: Statyi, Pis'ma, Vospominaniya [Nevel collected works: Essays, letters, and memoirs]. St. Petersburg, Akropol, pp. 61-75.

Laptun, V. I. (2010). M. M. Bakhtin in the 1960s - 1970s: Saransk - Moscow (from the memories of his friends and colleagues). Strannik, 6, pp. 147-152.

Laptun, V. \& Tihanov, G. (2018). Pedagogical work of Mikhail M. Bakhtin (1920s - early 1960s) // Dialogic Pedagogy: An International Online Journal | http://dpj.pitt.edu DOI: 10.5195/dpj.2018.248 | 6, pp. 18-18.

Matusov, E., Marjanovic-Shane, A., \& Gradovski, M. (2019). Dialogic pedagogy and polyphonic research art: Bakhtin by and for educators, doi: 10.1057/978-1-137-58057-3. New York: Palgrave Macmillan.

Mirkina, R. (1993). Bakhtin, as I knew him (Young Bakhtin) [Bakhtin, kakim ya yego znala (Molodoy Bakhtin)] // Dialogue. Carnival. Chronotope. 1, pp. 92-96.

Nikolaev, N. (1998). The publication of Bakhtin's heritage as a philological problem [lzdaniye naslediya Bakhtina kak filologicheskaya problema] // Dialog, Karnaval, Khronotop, 3, pp. 114-157.

Nikolaev, N. (2017) Teptelkin i drugiye v romane Konst. Vaginova "Kozlinaya pesn" [Teptyolkin and others in the novel by Const. Vaginova "Goat song"] // Literaturnyy fakt, 4, pp. 233-267.

Osovsky, O. (1993). Chelovek. Slovo. Roman. (Nauchnoye naslediye M. M. Bakhtina i sovremennost') [Person. Word. Novel. (The scientific heritage of M. M. Bakhtin and modernity)]. Saransk: RIK Trio.

Osovsky, O. (2017). Bol'shoye vremya idey: myshleniye M. M. Bakhtina skvoz' prizmu sovremennosti [The great time of ideas: the thinking of M. M. Bakhtin through the prism of modernity] // Russkaya literatura. 1, pp. 252-253.

Osovsky, O. (2018). The destinies of meta-criticism in the era of mega-crisis // Social Sciences. 49 (2), pp. $132-143$.

Osovsky, O. \& Kirzhaeva, V. (2017). С.И. Гессен и журнал «Русская школа за рубежом»: Из истории педагогической журналистики русского зарубежья 1920-х - начала 1930-x [S.I. Gessen and the Russkaya shkola za rubezhom journal: From the history of the Russian émigré pedagogical journalism of the 1920s - The beginning of the 1930s] // Vestnik Tomskogo Gosudarstvennogo Universiteta, Filologiya, 48, pp. 202-228. 


\section{Education-for-Myself and Education-for-the Other: The Right to Freedom of Education and Mikhail Bakhtin's Experience}

Oleg Osovsky, Vera Kirzhaeva, Ekaterina Chernetsova, Elizaveta Maslova

Pan'kov, N. (1998) Архивные материалы о невельском периоде биографии М.М. Бахтина // Nevelskiy Sbornik: Statyi, Pis'ma, Vospominaniya [Nevel collected works: Essays, letters, and memoirs]. St. Petersburg, Akropol,

Pan'kov, N. (2010). Voprosy biografii i nauchnogo tvorchestva M. M. Bakhtina [Questions of biography and scientific creativity of M. M. Bakhtin]. Moscow: Izdatel'stvo Moskovskogo universiteta.

Yudina, M. V. (2006). Vysokiy stoykiy dukh. Perepiska 1918-1945 gg. [High persistent spirit. Correspondence 1918]. Moscow: ROSSPEN.

\section{(c)) EY}

New articles in this journal are licensed under a Creative Commons Attribution 4.0 United States License.
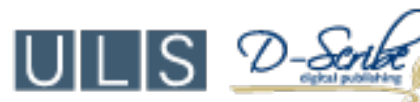

This journal is published by the University Library System, University of Pittsburgh as part of its D-Scribe Digital Publishing Program and is cosponsored by the University of Pittsburgh Press. 